\title{
Perbandingan Metode Sobel, Prewitt, Robert dan Canny pada Deteksi Tepi Objek Bergerak
}

\author{
Wahyu Supriyatin \\ Universitas Gunadarma, Jalan Margonda Raya No. 100, Depok 16424, Indonesia \\ ayu_ws@staff.gunadarma.ac.id
}

\begin{tabular}{|c|c|}
\hline INFORMASI ARTIKEL & ABSTRAK \\
\hline $\begin{array}{l}\text { Diterima } \quad: 23 \text { Maret } 2020 \\
\text { Diulas } \quad: 23 \text { Juni } 2020 \\
\text { Direvisi }: 05 \text { Agustus } 2020 \\
\text { Diterbitkan }: 27 \text { Agustus } 2020 \\
\text { Kata Kunci: } \\
\text { Canny } \\
\text { Deteksi tepi } \\
\text { Prewitt } \\
\text { Robert } \\
\text { Sobel }\end{array}$ & $\begin{array}{l}\text { Computer vision merupakan bidang ilmu dari image processing. Untuk dapat } \\
\text { mengenali bentuk, diperlukan tahapan awal dalam image processing yaitu } \\
\text { deteksi tepi. Objek yang digunakan dalam pelacakan di computer vision adalah } \\
\text { objek bergerak (video). Deteksi tepi digunakan untuk mengenali tepi dari objek } \\
\text { dan mengurangi noise yang ada. Algoritma deteksi tepi yang digunakan dalam } \\
\text { penelitian adalah Sobel, Prewitt, Robert dan Canny. Pengujian dilakukan } \\
\text { terhadap tiga buah video yang diambil dari library Matlab. Pengujian dilakukan } \\
\text { dengan menggunakan tools Simulik Matlab. Hasil pengujian edges dan overlay } \\
\text { menunjukkan bahwa algoritma Prewitt memiliki hasil deteksi tepi lebih baik } \\
\text { dibandingkan dengan algoritma lain. Algoritma Prewitt menghasilkan edge } \\
\text { yang tingkat akurasinya lebih halus dan lebih jelas seperti objek asli. Algoritma } \\
\text { Canny tidak berhasil menghasilkan edge pada objek video. Algoritma Sobel dan } \\
\text { Robert dapat mendeteksi edge tetapi tidak jelas seperti Prewitt karena ada } \\
\text { beberapa tepi yang hilang. }\end{array}$ \\
\hline
\end{tabular}

$\begin{array}{ll}\text { Keywords: } & \text { ABSTRACT } \\ \text { Canny } & \text { Computer vision is one of field of image processing. To be able to recognize } \\ \text { Edge detection } & \text { shapes, it requires the initial stages in image processing, namely as edge } \\ \text { Prewitt } & \text { detection. The object used in tracking in computer vision is a moving object } \\ \text { Robert } & \text { exiseo). Edge detection is used to recognize edges of objects and reduce } \\ \text { Sobel } & \text { Prewitt, Robert and Canny. Tests were carried out on three videos taken from } \\ & \text { the Matlab library. Testing is done using Simulik Matlab tools. The edge and } \\ & \text { overlay test results show that the Prewitt algorithm has better edge detection } \\ & \text { results compared to other algorithms. The Prewitt algorithm produces edges } \\ \text { which level of accuracy is smoother and clearer like the original object. The } & \text { Canny algorithm failed to produce an edge on the video object. On the other } \\ & \text { hand, the Sobel and Robert algorithm can detect edges but it is not as clear as } \\ & \text { Prewitt does, because there are some missing edges. }\end{array}$

This is an open access article under the CC-BY-SA license.

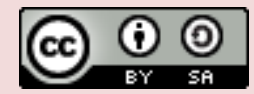

\section{Pendahuluan}

Citra digital didapatkan dari sekumpulan gambar maupun video [1]. Seiring berkembangnya teknologi, kini teknik pengolahan citra digital akan dikembangkan menjadi computer vision [1]. Computer vision merupakan ilmu yang menggunakan image processing untuk membuat keputusan dengan berdasarkan citra yang didapat dari sensor [2]. Computer vision dan penglihatan manusia memiliki fungsi yang sama, dengan tujuan menafsirkan data spasial yaitu data yang diindeks lebih dari satu dimensi [3]. Teknik computer vision dapat mereplikasi dengan tepat fungsi mata manusia dan memperbaiki sistem penglihatan manusia [3].

Pelacakan objek merupakan bentuk penerapan aplikasi computer vision [1]. Untuk dapat melakukan pelacakan suatu objek diperlukan suatu tahapan dalam proses pengolahan citra. Pengolahan Citra (Image Processing) merupakan bidang yang berhubungan dengan proses transformasi citra/gambar (image) [4]. Proses pengolahan citra dilakukan untuk mendapatkan kualitas citra yang lebih baik [4]. Pendeteksian tepi merupakan salah satu tahapan awal yang ada dalam proses pengolahan citra. Deteksi tepi digunakan untuk memperoleh tepi objek dengan memanfaatkan perubahan nilai intensitas yang drastis pada batas dua area [5]. Deteksi tepi adalah himpunan piksel yang terhubung yang terletak pada batas dua area [5]. 
Tujuan mendeteksi tepi adalah untuk mengelompokkan objek-objek dalam citra dan juga digunakan untuk menganalisa citra lebih lanjut [6]. Deteksi tepi dibagi menjadi dua golongan, yaitu golongan pertama disebut deteksi tepi orde pertama dan golongan kedua disebut deteksi tepi orde kedua [5]. Deteksi tepi orde pertama bekerja dengan menggunakan turunan atau diferensial orde pertama, yang termasuk dalam orde pertama adalah Sobel, Prewitt, Robert dan Canny [5]. Deteksi orde kedua menggunakan turunan orde kedua yaitu Laplacian of Gaussian (LoG) [5].

Sobel adalah metode edge detection yang termasuk dalam gradient edge detector [5]. Prewitt memiliki persamaan gradien dengan Sobel tetapi dengan nilai konstantan sama dengan 1 [7]. Robert disebut juga dengan operator silang karena arah $x$ dan arah $y$ diagonal dalam kuadran 1 [7]. Canny adalah metode yang digunakan dengan pendekatan konvolusi fungsi gambar dengan operator gaussian dan turunannya [5].

Tujuan dari penelitian ini adalah melakukan analisis perbandingan metode deteksi tepi dengan menggunakan objek bergerak (video). Perbandingan deteksi tepi dilakukan dengan menggunakan empat buah algoritma yaitu algoritma Sobel, Prewitt, Robert dan Canny. Deteksi tepi dilakukan sebagai tahap awal dalam pengenalan/pelacakan objek untuk dapat digunakan dalam proses pengolahan citra selanjutnya. Proses perbandingan deteksi tepi dilakukan dengan menggunakan tools Simulink Matlab. Hasil dari deteksi tepi video dibandingkan dengan menggunakan simulasi parameter dari masing-masing algoritma. Hasil pengujian digunakan untuk melihat ketebalan dan ketepatan parameter dalam mendeteksi tepi dari objek. Sehingga bentuk objek menjadi lebih jelas sekalipun dalam kondisi bergerak.

Penelitian sebelumnya yang telah dilakukan tentang deteksi tepi sebagai pengenalan bentuk pada citra digital antara lain: Derisma tahun 2016 [5], melakukan penelitian dengan input gambar untuk tentang teknik deteksi tepi Sobel, Canny dan Laplace. Pengujian pendeteksian tepi dilakukan dengan melihat pada kecepatan konversi suatu objek yang berpengaruh terhadap variasi gambar, resolusi gambar, format gambar, spesifikasi kamera dan spesifikasi laptop yang digunakan. Hasil penelitian menunjukkan bahwa metode deteksi tepi Canny lebih efektif karena output yang dihasilkan lebih detail dan jelas serta waktu eksekusinya paling cepat dibandingkan dengan metode lain. Tahun 2011, Winarno [7] dengan penelitian pendeteksian tepi pada realtime video dengan menggunakan algoritma Canny detection. Hasil penelitian diperoleh bahwa algoritma Canny detection dapat memberikan hasil deteksi tepi yang optimal dan mampu memberikan hasil sesuai dengan parameter konvolusi yang dilakukan. Nilai fleksibilitas Canny lebih tinggi dalam mendeteksi ketebalan tepi dari objek yang dicari. Canny edge detection membutuhkan suatu memori komputer yang tinggi dalam melakukan proses data gambar video. Kurniawati dkk [6] penelitian dilakukan dengan menggunakan GUI Matlab pada pola wajah. Metode Canny edge detection digunakan untuk mendeteksi semua tepi atau garis dari objek wajah. Metode Canny digunakan karena dapat mengurangi noise sebelum dilakukan perhitungan deteksi tepi. Deteksi dilakukan untuk melakukan pengenalan wajah agar dapat dibedakan antara pola wajah dengan pola yang lainnya. Hasil penelitian menunjukkan metode Canny jelas memperoleh hasil dengan melakukan perhitungan nilai gradient dan arah orientasi horizontal dan vertical. Penelitian dengan menggunakan operator deteksi tepi Canny lebih baik dari pada operator Sobel, karena operator Canny mendeteksi tepi yang sebenarnya dan tidak menghilangkan tepi sebenarnya. Sedangkan operator Sobel ada tepi sebenarnya yang hilang dan memunculkan tepi yang bukan tepi sebenarnya. Penelitian yang dilakukan oleh Nurullah [8] pada citra digital dengan operator Sobel dapat menghasilkan tepi yang lebih tebal dibandingkan operator Canny.

Penelitian perbandingan pendeteksian tepi pada citra USG janin dua dimensi dilakukan oleh [9], penelitian dilakukan dengan membandingkan tiga metode pendeteksian tepi yaitu Sobel, Canny dan Laplacian of Gaussian (LOG). Penelitian dilakukan dengan melakukan tahapan pengolahan citra untuk memperoleh bentuk citra USG janin. Penelitian dilakukan untuk menentukan metode mana yang paling baik dalam mengenali bentuk citra USG janin dua dimensi. Hasil penelitian menunjukkan bahwa citra USG janin dua dimensi baik dideteksi dengan menggunakan metode Canny, karena dapat menghasilkan garis tepi yang tebal dan jelas untuk citra USG janin. Penelitian citra medis juga dilakukan oleh [10] tentang citra medis tulang. Metode deteksi tepi digunakan untuk menentukan keretakan atau patah pada tulang. Penelitian dilakukan dengan menggunakan metode Sobel untuk mengidentifikasi garis batas atau tepian pada objek, selain itu metode Sobel memiliki kelebihan dapat mengurangi derau dari metode deteksi tepi lain. Citra yang digunakan dalam penelitian adalah tiga buah sampel citra dengan dilakukan perbaikan citra terlebih dahulu menggunakan transformasi fourier untuk mengurangi derau citra. Hasil dari pengujian menunjukkan deteksi tepi citra tulang harus dilakukan proses perbaikan terlebih dahulu sebelum dilakukan proses deteksi tepi Sobel. Penelitian perbandingan deteksi tepi pada citra digital menggunakan metode Prewitt, Sobel dan Canny dilakukan Sukatmi [11]. Penelitian dilakukan pada enam buah citra digital, dimana dari metode yang dilakukan ternyata metode Canny dapat menghasilkan deteksi tepi citra lebih baik dibandingkan dengan metode Sobel dan metode Sobel lebih baik dari metode Prewitt. Hasil penelitian deteksi tepi menunjukkan jumlah piksel warna putih dengan metode Canny lebih besar dibandingkan dengan metode Sobel dan Prewitt.

Perbandingan deteksi tepi dengan menggunakan Sobel, Prewitt dan Robert telah dilakukan oleh [12] pada citra digital. Penelitian dilakukan untuk mengukur tingkat pengenalan hasil deteksi tepi serta memperoleh informasi awal dalam pengenalan objek citra. Dari penelitian yang dilakukan terhadap citra digital bangun ruang tanpa background menunjukkan metode Prewitt memiliki tingkat akurasi yang lebih bagus 
dibandingkan kedua metode yang lainnya dalam mendeteksi tepi dan mengenali bentuk bangun ruang dua dimensi.

Perbandingan deteksi tepi menggunakan metode Sobel, Prewitt, Robert dan Canny yang dilakukan pada penelitian ini menggunakan citra bergerak (citra realtime) dalam bentuk video. Tools yang digunakan dalam penelitian ini adalah Simulink Matlab, dimana dilakukan perbandingan parameter dari masing-masing algoritma. Parameter yang diuji adalah Source Block Parameter dan Function Block Parameter. Objek dalam penelitian ini menggunakan video realtime (video bergerak) tanpa melakukan akuisisi citra terlebih dahulu menjadi bentuk image. Penelitian sebelumnya yang telah dilakukan menggunakan citra digital dalam bentuk image (citra statis) sebagai objeknya. Penelitian sebelumnya ada yang menggunakan citra realtime [7] tetapi hanya menggunakan satu metode yaitu metode Canny dan tools yang digunakan adalah OpenCV. Penelitian sebelumnya menggunakan video realtime yang kemudian diakuisisi menjadi bentuk image untuk selanjutnya diproses deteksi tepi Canny.

\section{Metode}

Metode yang digunakan dalam penelitian adalah metode pengumpulan data, dengan mencari objek video yang digunakan sebagai objek deteksi tepi. Penelitian dilakukan dengan mempelajari buku-buku yang berkaitan dengan deteksi tepi objek bergerak; mempelajari tools yang digunakan dalam algoritma deteksi tepi Sobel, Prewitt, Robert dan CannyI; dan mempelajari tools yang akan digunakan dalam Simulink Matlab untuk proses deteksi tepi serta mencari video objek bergerak dalam library Matlab. Penelitian dilakukan dengan menerapkan algoritma Sobel, Prewitt, Robert dan Canny untuk mendeteksi tepi objek. Pendeteksian tepi dilakukan dengan membandingkan tebal dan tipis garis tepi yang dihasilkan darimasing-masing objek. Kecepatan objek bergerak dalam video juga mempengaruhi bentuk tepi yang dihasilkan. Alur tahapan penelitian ini dapat dilihat pada Gambar 1.

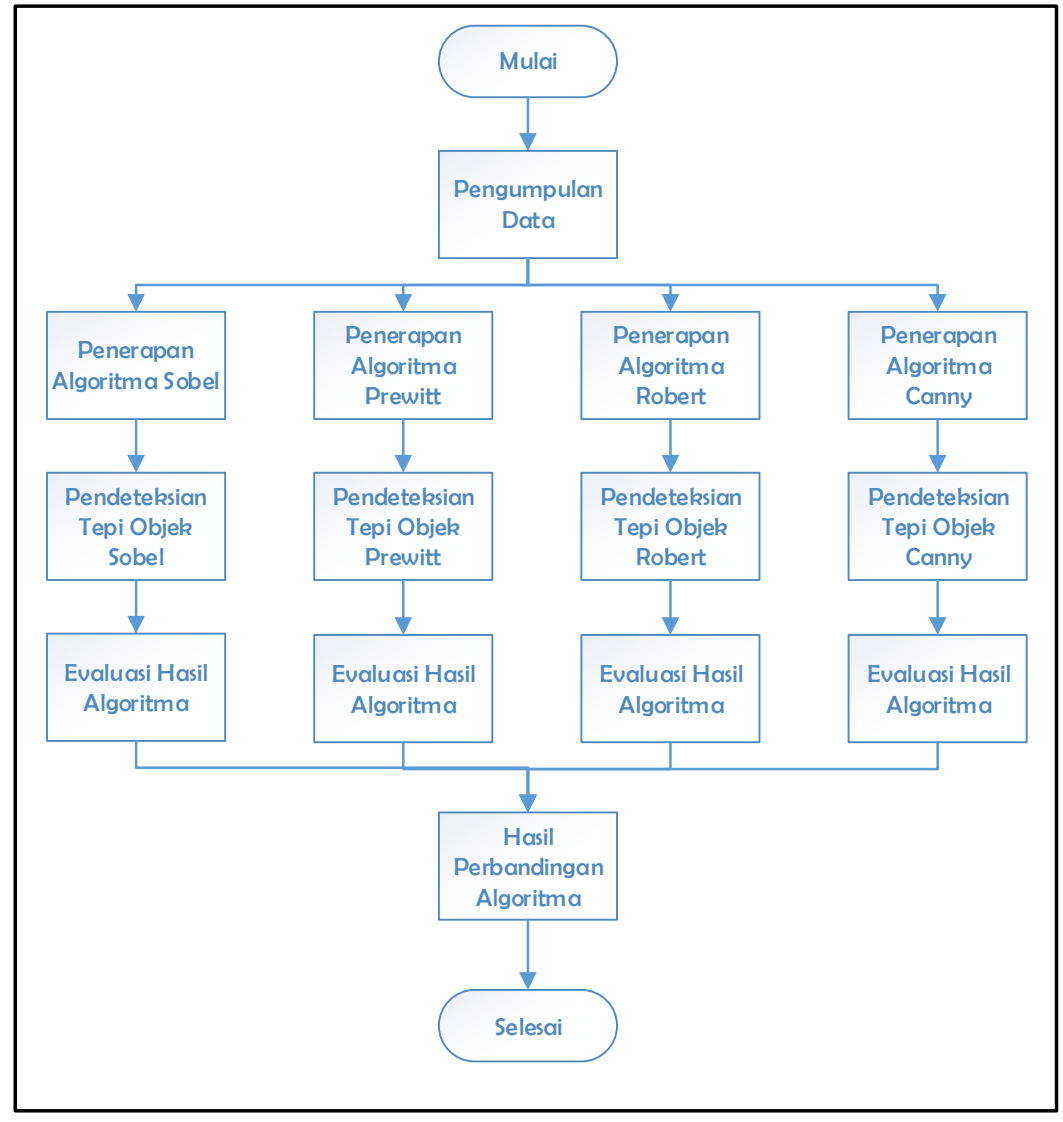

Gambar 1. Alur Tahap Penelitian

Metode Sobel merupakan salah satu pengembangan metode Robert dengan menggunakan High Pass Filter (HPF) yang diberi satu angka nol sebagai penyangga [13],[14]. Algoritma ini termasuk algoritma yang berfungsi sebagai filter image [13] [14]. Metode deteksi tepi Sobel adalah operator yang menggunakan matriks neighbor berukuran $3 \times 3$ dengan titik yang sedang diperiksa sebagai titik tengah matriks [10]. Operator Sobel diterapkan dalam dua buah matriks mask, yaitu matriks yang berukuran $n \times n$ yang sama dengan matriks neighbor [10]. Algoritma deteksi tepi Sobel dalam penelitian dapat dilihat pada Gambar 2. Video akan dimasukkan kedalam video source sebagai video asli dan akan diubah menjadi video biner dalam proses compositing untuk ditampilkan dalam nilai 0 dan 1. 


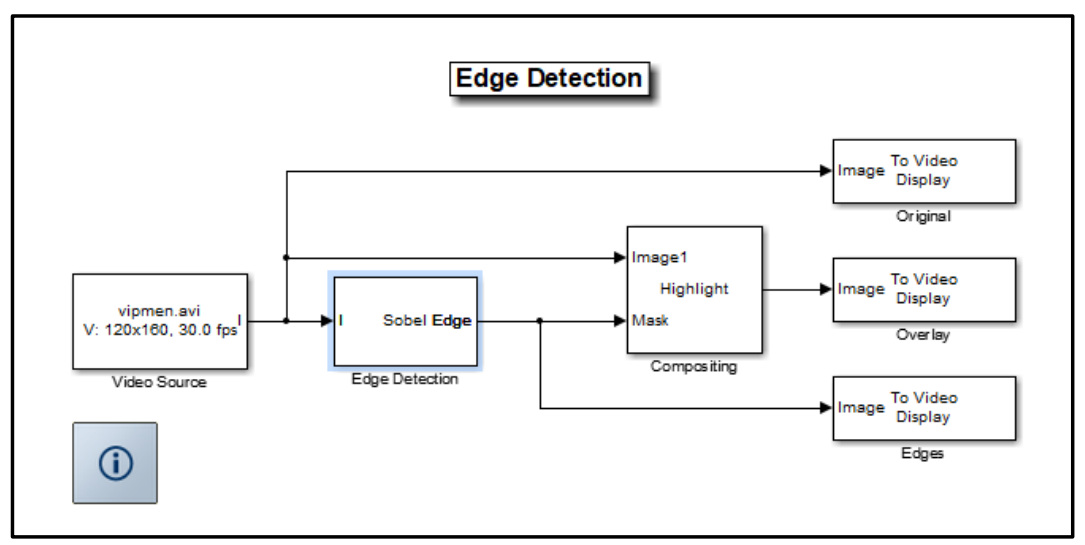

Gambar 2. Algoritma Deteksi Tepi Sobel

Metode deteksi tepi Prewitt merupakan pengembangan metode Robert dengan menggunakan High Pass Filter (HPF) yang diberi satu angka nol penyangga [11]. Metode Prewitt mengambil prinsip dari fungsi Laplacian yaitu membangkitkan HPF [11]. Deteksi tepi Prewitt dilakukan secara parsial dengan arah yang berlawanan dengan arah fungsi turunan pertama dan merupakan hasil gabungan dari konvolusi gradient Prewitt arah $x$ dengan arah $y$ [15]. Gambar 3 adalah algoritma Prewitt untuk deteksi tepi objek video. Objek bergerak dengan kecepatan gerak yang berbeda dapat mempengaruhi deteksi tepi yang dihasilkan.

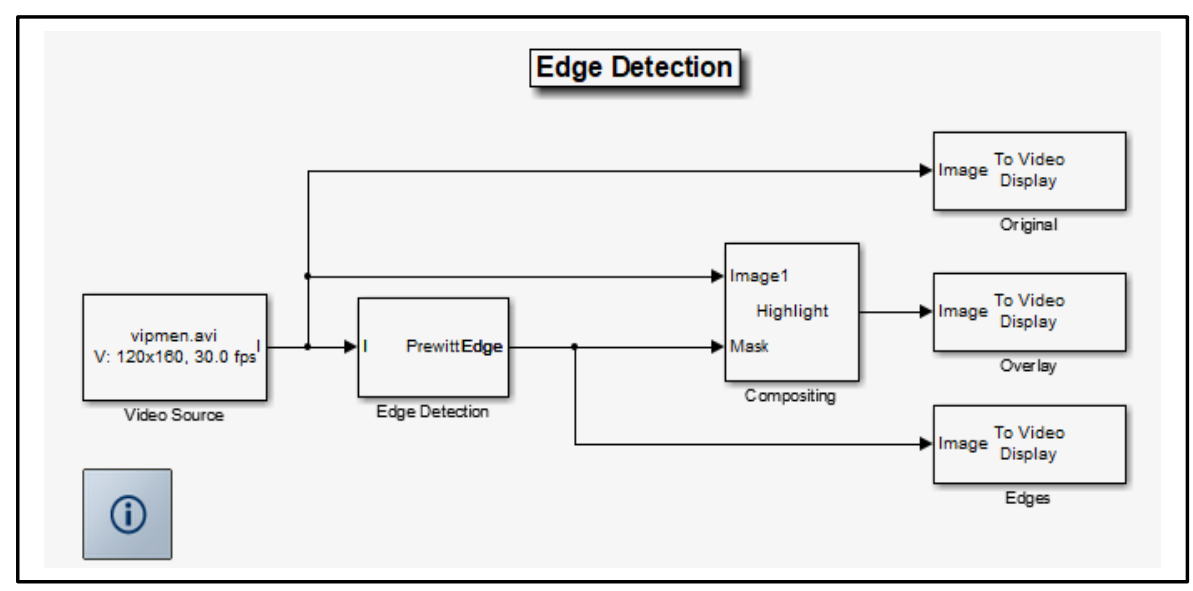

Gambar 3. Algoritma Deteksi Tepi Prewitt

Metode deteksi tepi Roberts adalah operator pendeteksian tepi dengan berbasis gradient dengan menggunakan dua buah Kernel berukuran $2 \times 2$ piksel [16]. Operator Roberts mengambil arah diagonal untuk penentuan arah serta mencari perbedaan (differensial) pada arah horizontal dan perbedaan vertical, dengan ditambahkan proses konversi biner [16]. Gambar 4 merupakan algoritma deteksi tepi Robert dengan menggunakan tools Simulink Matlab. Video asli intensity akan dimasukkan dengan mengalami perubahan bentuk menjadi biner dan akan mengalami perlambatan pergerakan objek untuk dideteksi tepi.

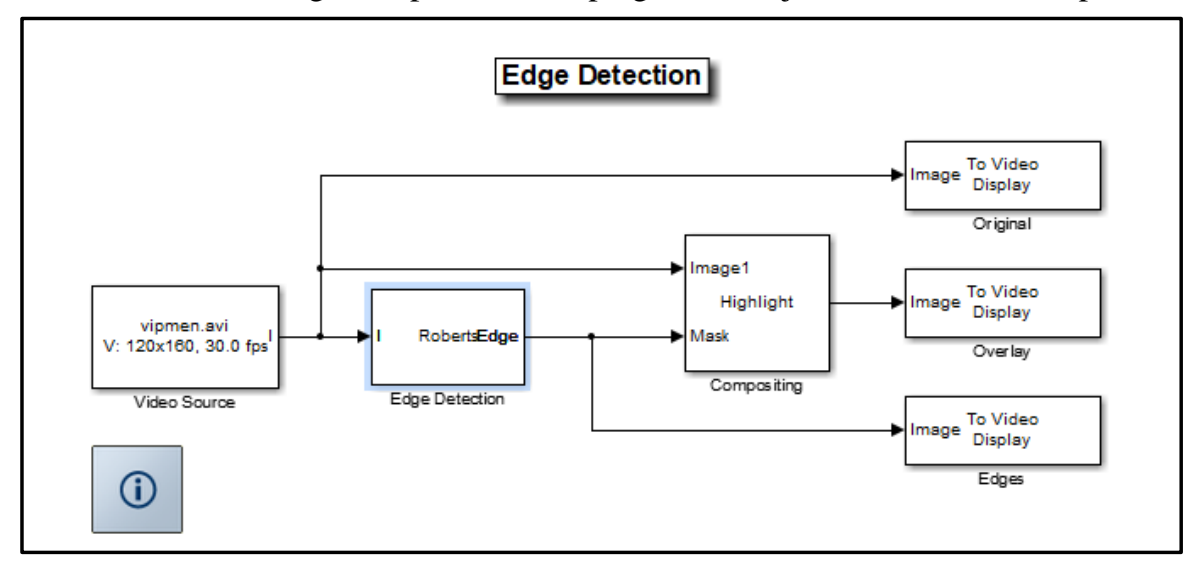

Gambar 4. Algoritma Deteksi Tepi Robert 
Metode deteksi tepi Canny adalah metode deteksi tepi yang akan menghasilkan tampilan gambar yang berbeda dari semua metode karena menampilkan efek relief di dalamnya [11]. Kelebihan metode Canny adalah kemampuan untuk mengurangi noise sebelum melakukan perhitungan tepi sehingga tepi yang dihasilkan akan lebih banyak. Deteksi tepi Canny dapat mendeteksi tepi yang sebenarnya dengan tingkat error minimum dan menghasilkan tepi yang optimal [11]. Gambar 5 adalah algoritma deteksi tepi Canny, mulanya video dimasukkan ke dalam video sumber yang dikenali sebagai video dengan input single. Video akan mengalami proses deteksi tepi Canny yang akan mengubah citra menjadi bentuk biner (0 dan 1). Video biner ini akan menunjukkan ketebalan dan ketipisan dari tepi objek yang dihasilkan.

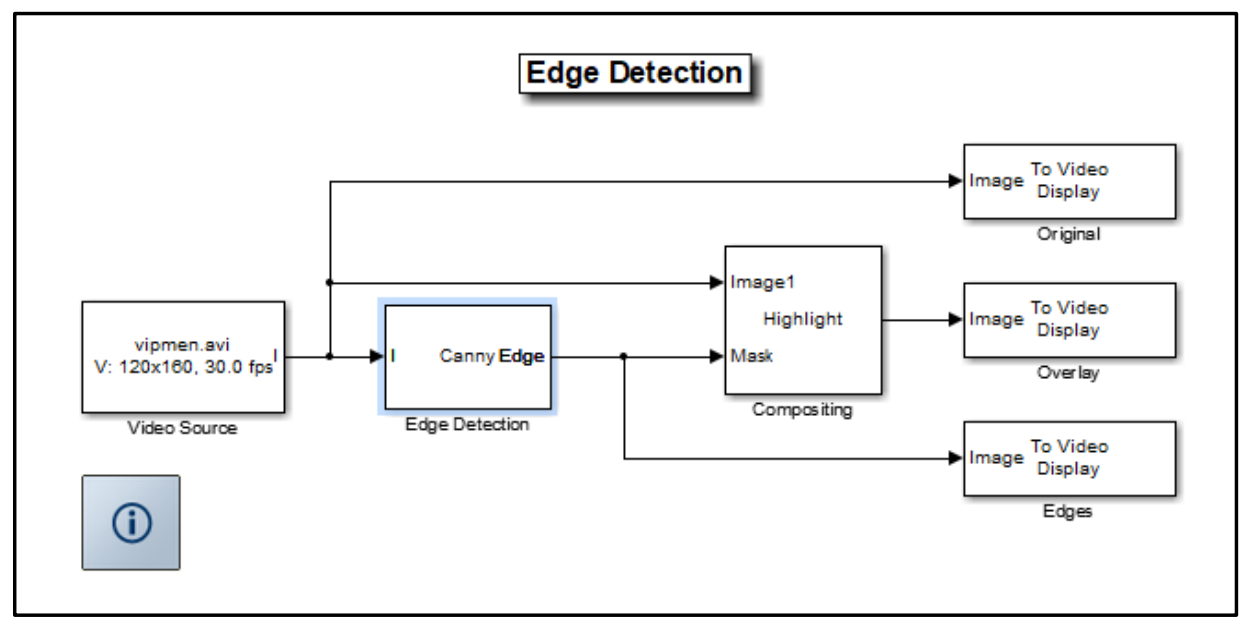

Gambar 5. Algoritma Deteksi Tepi Canny

\section{Hasil dan Pembahasan}

Penelitian ini membandingkan empat algoritma deteksi tepi, yaitu algoritma deteksi tepi Sobel, Prewitt, Robert dan Canny. Deteksi tepi dalam penelitian ini digunakan untuk mengenali objek bergerak yang melintas dari video yang digunakan. Video yang digunakan dalam penelitian berjumlah tiga buah dengan ukuran :

1. Video Vipmen.avi (resolusi $=120 \times 160 ;$ frame $=30.0 \mathrm{fps}$ )

2. Video Vipcolorsegmentation.avi (resolusi $=120 \times 160 ;$ frame $=15.0 \mathrm{fps}$ )

3. Video Visionface.avi (resolusi $=480 \times 640$; frame $=30.0 \mathrm{fps}$ )

Kondisi yang digunakan dalam penelitian perbandingan ketiga video adalah :

1. Video Vipmen.avi (kamera yang digunakan untuk mengambil objek memiliki jarak 2 m; memiliki sedikit background video; kecepatan objek bergerak 1-2 km/jam)

2. Video Vipcolorsegmentation.avi (kamera yang digunakan untuk mengambil objek memiliki jarak 2 $\mathrm{m}$; memiliki banyak background video; kecepatan objek bergerak 1-2 km/jam)

3. Video Visionface.avi (kamera yang digunakan untuk mengambil objek memiliki jarak 2 m; memiliki sedikit background video; kecepatan objek bergerak 3-4 km/jam)

Ketiga video diambil dengan menggunakan kamera diam yang diletakkan pada satu posisi atau tempat, sedangkan objek yang akan diambil atau diamati mengalami pergerakan atau perpindahan posisi. Video yang digunakan dalam penelitian diambil dari library Matlab. Parameter yang digunakan dalam penelitian perbandingan ketiga metode adalah :

1. Source Block Parameters

2. Function Block Parameters

Parameter yang digunakan dalam simulasi untuk source block parameters dan function block parameters dapat dilihat pada Tabel 1. Hasil yang akan diperoleh dalam penelitian perbandingan empat algoritma adalah tiga buah output video yaitu :

1. Video Original

2. Video Overlay

3. Video Edges

Tabel 1. Parameter Simulasi

\begin{tabular}{|c|c|c|c|c|}
\hline $\begin{array}{c}\text { Jenis } \\
\text { Parameter }\end{array}$ & $\begin{array}{c}\text { Algoritma Deteksi } \\
\text { Tepi Sobel }\end{array}$ & $\begin{array}{c}\text { Algoritma Deteksi } \\
\text { Tepi Prewitt }\end{array}$ & $\begin{array}{c}\text { Algoritma Deteksi } \\
\text { Tepi Robert }\end{array}$ & $\begin{array}{c}\text { Algoritma Deteksi } \\
\text { Tepi Canny }\end{array}$ \\
\hline $\begin{array}{l}\text { Source Block Parameters } \\
\text { (Video Source: } \\
\text { Multimedia File) }\end{array}$ & $\begin{array}{l}\text { - Number of times to } \\
\text { play file: inf } \\
\text { - Output Color Format: }\end{array}$ & $\begin{array}{l}\text { - Number of times to } \\
\text { play file: inf } \\
\text { - Output Color Format: }\end{array}$ & $\begin{array}{l}\text { - Number of times to } \\
\text { play file: inf } \\
\text { - Output Color Format: }\end{array}$ & $\begin{array}{l}\text { - Number of times to } \\
\text { play file: inf } \\
\text { - Output Color Format: }\end{array}$ \\
\hline
\end{tabular}




\begin{tabular}{|c|c|c|c|c|}
\hline $\begin{array}{c}\text { Jenis } \\
\text { Parameter }\end{array}$ & $\begin{array}{c}\text { Algoritma Deteksi } \\
\text { Tepi Sobel }\end{array}$ & $\begin{array}{c}\text { Algoritma Deteksi } \\
\text { Tepi Prewitt }\end{array}$ & $\begin{array}{c}\text { Algoritma Deteksi } \\
\text { Tepi Robert }\end{array}$ & $\begin{array}{c}\text { Algoritma Deteksi } \\
\text { Tepi Canny }\end{array}$ \\
\hline & Intensity & Intensity & Intensity & Intensity \\
\hline \multirow[t]{2}{*}{$\begin{array}{l}\text { Function Block } \\
\text { Parameter (Edge } \\
\text { Detection) }\end{array}$} & $\begin{array}{l}\text { - Output type: Binary } \\
\text { image } \\
\text { - Threshold source: } \\
\text { Spacity via dialog }\end{array}$ & $\begin{array}{l}\text { - Output type: Binary } \\
\text { image } \\
\text { - Threshold source: } \\
\text { Spacity via dialog }\end{array}$ & $\begin{array}{l}\text { - Output type: Binary } \\
\text { image } \\
\text { - Threshold source: } \\
\text { Spacity via dialog }\end{array}$ & $\begin{array}{l}\text { - Output type: Binary } \\
\text { image } \\
\text { - Threshold source: } \\
\text { Spacity via dialog }\end{array}$ \\
\hline & $\begin{array}{l}- \text { Threshold: } \\
(15 / 256)\end{array}$ & $\begin{array}{l}- \text { Threshold: } \\
(15 / 256)\end{array}$ & $\begin{array}{l}\text {-Threshold: } \quad \text { Single } \\
(15 / 256)\end{array}$ & $\begin{array}{l}- \text { Threshold: } \\
(15 / 256)\end{array}$ \\
\hline $\begin{array}{l}\text { Function } \quad \text { Block } \\
\text { Parameter (Compositing) }\end{array}$ & $\begin{array}{l}\text { - Operation: Highlight } \\
\text { selected pixels } \\
\text { - Location source: } \\
\text { Specify via dialog } \\
\text { - Location }[x \text { y }]:\left[\begin{array}{ll}1 & 1]\end{array}\right.\end{array}$ & $\begin{array}{l}\text { - Operation: Highlight } \\
\text { selected pixels } \\
\text { - Location source: } \\
\text { Specify via dialog } \\
\text { - Location }[x \text { y }]:\left[\begin{array}{ll}1 & 1]\end{array}\right.\end{array}$ & $\begin{array}{l}\text { - Operation: Highlight } \\
\text { selected pixels } \\
\text { - Location source: } \\
\text { Specify via dialog } \\
\text { - Location }[x \text { y }]:\left[\begin{array}{ll}1 & 1\end{array}\right]\end{array}$ & $\begin{array}{l}\text { - Operation: Highlight } \\
\text { selected pixels } \\
\text { - Location source: } \\
\text { Specify via dialog } \\
\text { - Location }\left[\begin{array}{ll}x & y\end{array}\right]:\left[\begin{array}{ll}1 & 1\end{array}\right]\end{array}$ \\
\hline
\end{tabular}

Gambar 6 sampai dengan Gambar 11 adalah hasil penelitian dengan simulasi parameter yang dilakukan seperti Tabel 1. Dari pengujian yang dilakukan terhadap objek diperoleh hasil video edges dan hasil video overlay.

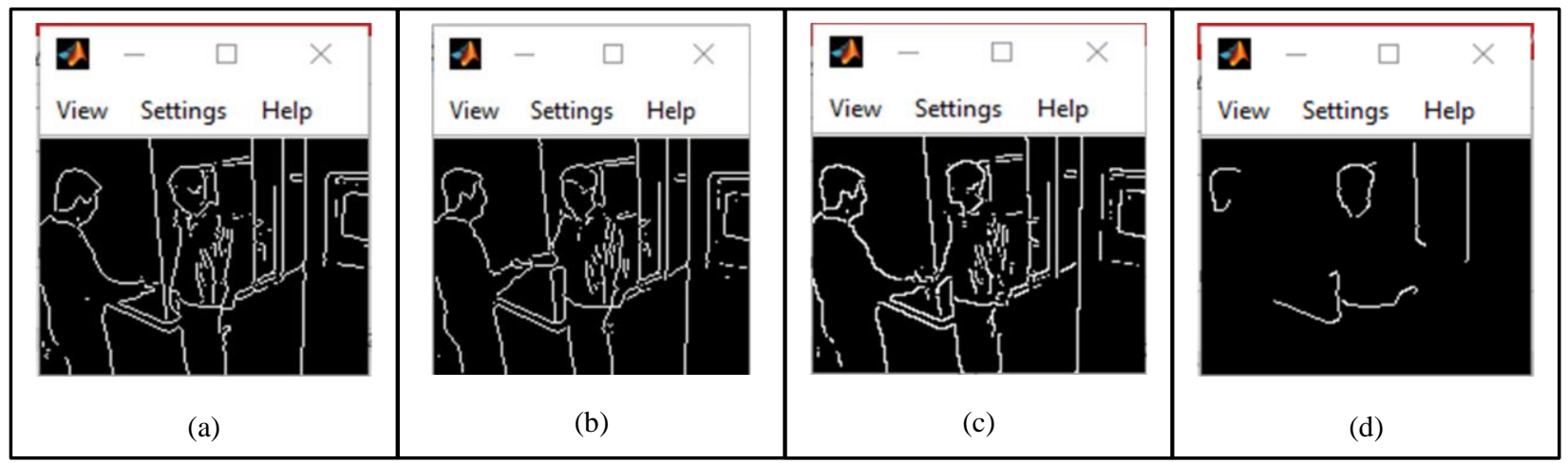

Gambar 6. Video Edges Vipmen.avi (a). Sobel (b). Prewitt (c). Robert (d). Canny

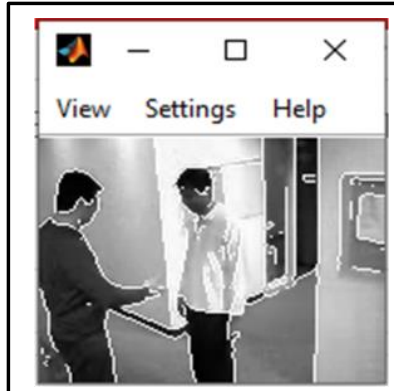

(a)

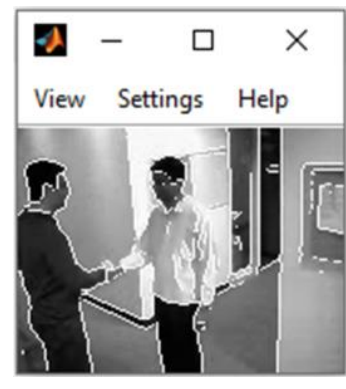

(b)

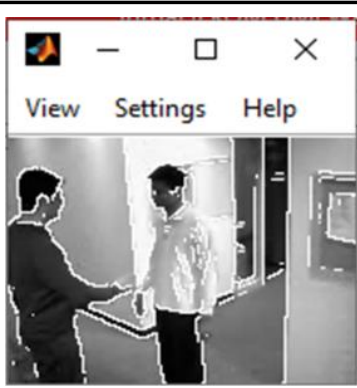

(c)

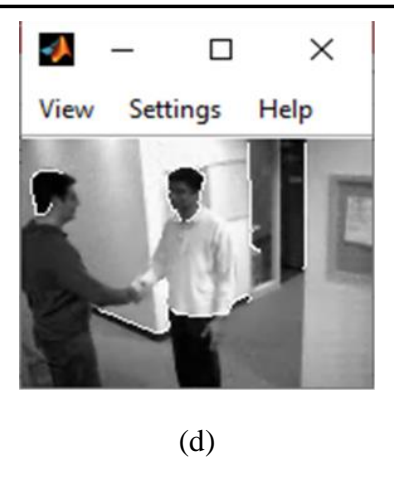

(d)

Gambar 7. Video Overlay Vipmen.avi (a). Sobel (b). Prewitt (c). Robert (d). Canny

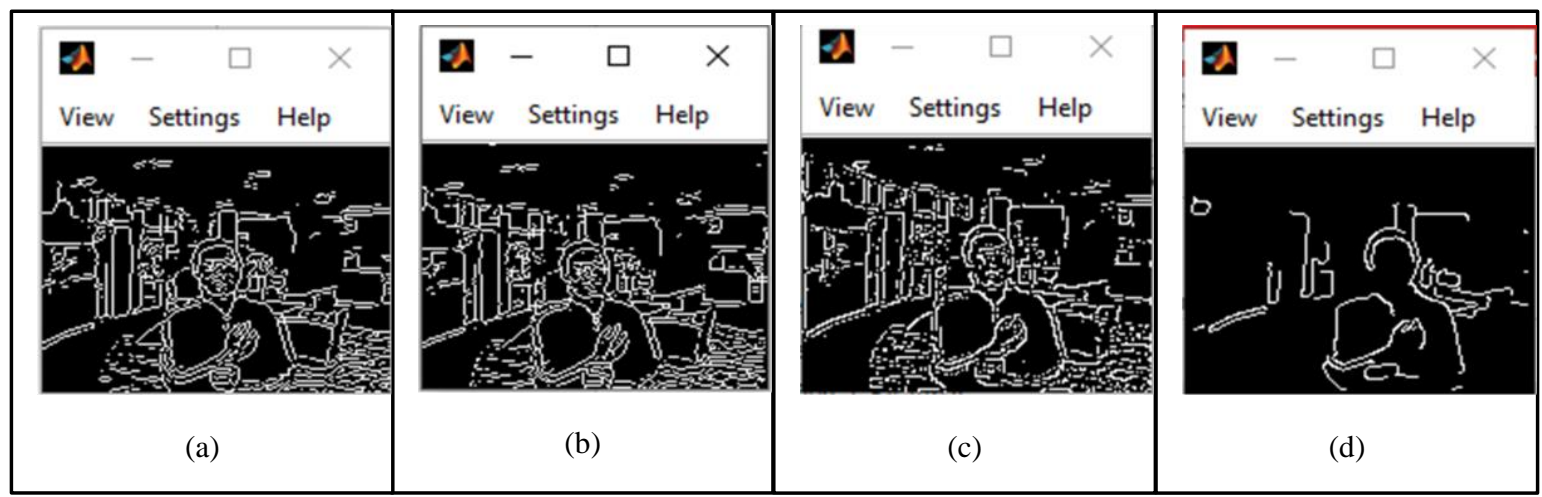

Gambar 8. Video Edges Vipcolorsegmentation.avi (a). Sobel (b). Prewitt (c). Robert (d). Canny 


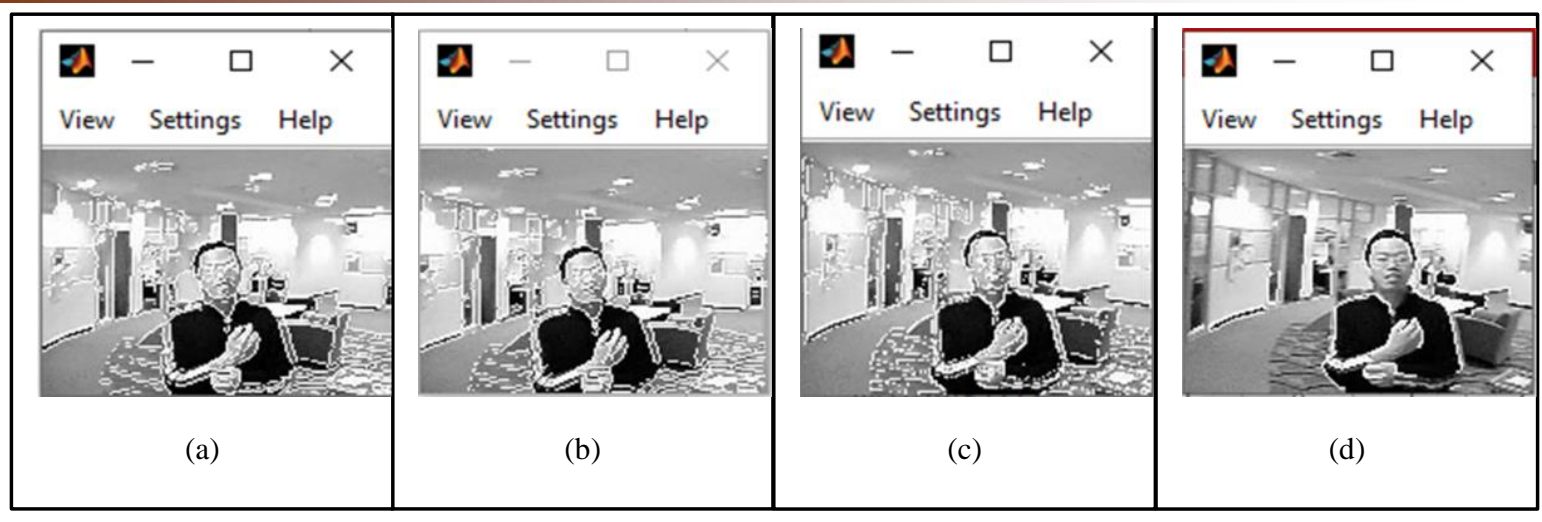

Gambar 9. Video Overlay Vipcolorsegmentation.avi (a). Sobel (b). Prewitt (c). Robert (d). Canny

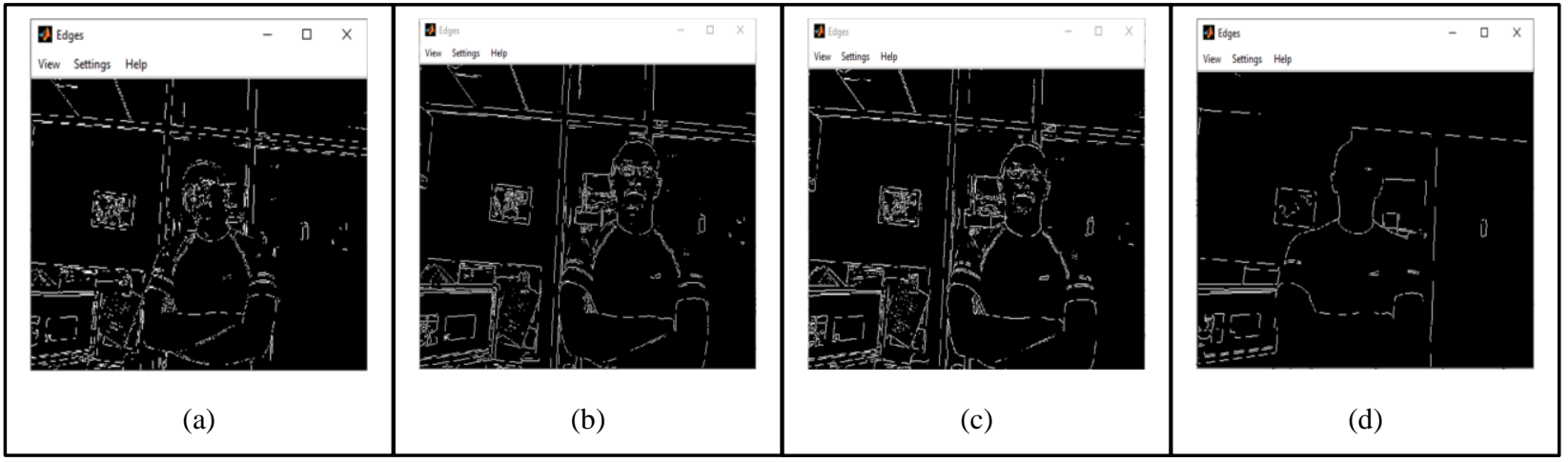

Gambar 10. Video Edges Visionface.avi (a). Sobel (b). Prewitt (c). Robert (d). Canny

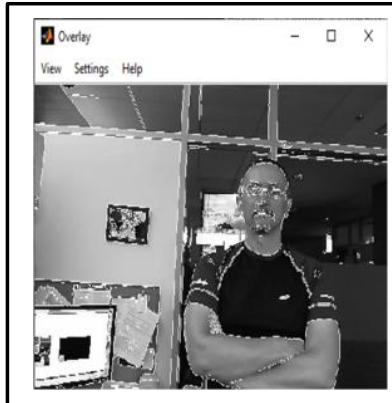

(a)

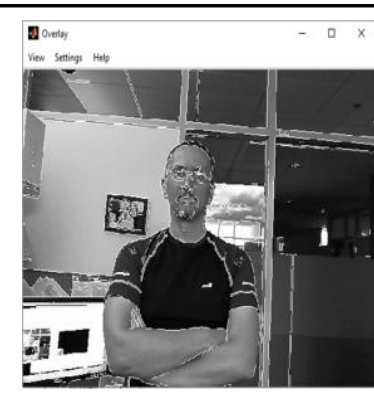

(b)

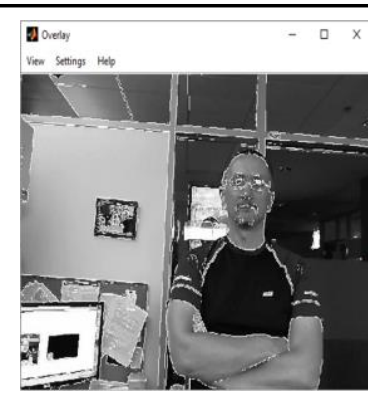

(c)

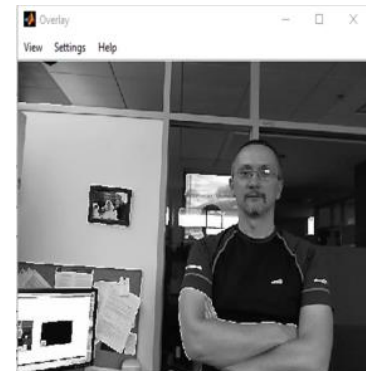

(d)

Gambar 11. Video Overlay Visionface.avi (a). Sobel (b). Prewitt (c). Robert (d). Canny

Tabel analisa pengujian antara keempat algoritma dengan menggunakan parameter simulasi seperti Tabel 1 dapat dilihat pada Tabel 2. Dari perbandingan keempat algoritma dengan tiga video bergerak yang digunakan menunjukkan bahwa video dengan algoritma Prewitt dapat menghasilkan tepi lebih baik dibandingkan ketiga algoritma yang lain. Tepi yang dihasilkan lebih halus dan mirip dengan aslinya dibandingkan yang lainnya.

Tabel 2. Analisa Pengujian

\begin{tabular}{|c|c|c|c|c|}
\hline Kriteria Analisa & $\begin{array}{c}\text { Algoritma Deteksi } \\
\text { Tepi Sobel }\end{array}$ & $\begin{array}{c}\text { Algoritma Deteksi } \\
\text { Tepi Prewitt }\end{array}$ & $\begin{array}{c}\text { Algoritma Deteksi } \\
\text { Tepi Robert }\end{array}$ & $\begin{array}{c}\text { Algoritma Deteksi } \\
\text { Tepi Canny }\end{array}$ \\
\hline \multirow[t]{2}{*}{ Edge Detection } & $\begin{array}{ll}\checkmark & \text { Berhasil } \\
\text { mendeteksi tepi } \\
\text { objek, tetapi tidak } \\
\text { semua objek } \\
\text { berhasil dideteksi. }\end{array}$ & $\begin{array}{l}\text { Berhasil mendeteksi } \\
\text { objek yang ada, } \\
\text { bahkan objek yang } \\
\text { berfungsi sebagai } \\
\text { background berhasil }\end{array}$ & $\begin{array}{l}\text { Berhasil } \\
\text { mendeteksi tepi } \\
\text { objek yang ada, } \\
\text { objek yang kecil } \\
\text { (background) ikut }\end{array}$ & $\begin{array}{ll} & \text { Tidak } \\
\text { mendeteksi } & \text { berhasil } \\
\text { objek } & \text { tepi } \\
\text { sempurna. } & \end{array}$ \\
\hline & $\begin{array}{llr}\checkmark & \text { Ada beberapa } \\
\text { objek-objek yang } \\
\text { hilang dan } & \text { tidak } \\
& \text { terdeteksi }\end{array}$ & $\begin{array}{l}\text { dideteksi. } \\
\checkmark \text { Deteksi tepi yang } \\
\text { dihasilkan lebih } \\
\text { halus dibandingkan } \\
\text { dengan robert. }\end{array}$ & $\begin{array}{l}\text { terdeteksi. } \\
\text { Deteksi tepi yang } \\
\text { dihasilkan lebih } \\
\text { tebal dibandingkan } \\
\text { dengan prewitt. } \\
\text { Tetapi ada tepi- } \\
\text { tepi yang halus }\end{array}$ & $\begin{array}{l}\text { yang hilang dan } \\
\text { tidak terdeteksi. }\end{array}$ \\
\hline
\end{tabular}




\begin{tabular}{|c|c|c|c|c|}
\hline Kriteria Analisa & $\begin{array}{c}\text { Algoritma Deteksi } \\
\text { Tepi Sobel }\end{array}$ & $\begin{array}{c}\text { Algoritma Deteksi } \\
\text { Tepi Prewitt } \\
\end{array}$ & $\begin{array}{c}\text { Algoritma Deteksi } \\
\text { Tepi Robert }\end{array}$ & $\begin{array}{c}\text { Algoritma Deteksi } \\
\text { Tepi Canny } \\
\end{array}$ \\
\hline & & & $\begin{array}{lr}\text { tidak terdeteksi } \\
\text { sehingga terlihat } \\
\text { hilang. }\end{array}$ & \\
\hline
\end{tabular}

\section{Kesimpulan dan Saran}

Deteksi tepi merupakan salah satu tahapan awal dalam proses image processing. Perbandingan deteksi tepi antara algoritma Sobel, Prewitt, Robert dan Canny berhasil menghasilkan tepi sesuai dengan objek yang digunakan. Algoritma Prewitt memiliki hasil deteksi tepi yang lebih baik dibandingkan dengan ketiga algoritma yang lain. Hasil deteksi tepi Prewitt lebih halus dibandingkan dengan Robert, karena Robert tepi yang dihasilkan lebih tebal sehingga ada tepi yang halus tidak terbaca. Algoritma Canny tidak berhasil melakukan deteksi tepi terhadap objek, sedangkan Sobel sama seperti Robert ada beberapa tepi yang hilang karena tidak terbaca. Hasil pengujian juga menunjukkan bahwa variasi gambar, resolusi gambar, format gambar dan spesifikasi letak kamera mempengaruhi hasil. Algoritma Prewitt memiliki tingkat akurasi yang baik dan efektif dalam mengenali objek karena tepi yang dihasilkan lebih jelas dan detail. Penelitian ini bersifat kuantitatif karena menggunakan data objektif video yang diambil dengan menggunakan kamera.

Pengembangan untuk penelitian selanjutnya pada video bergerak dapat menggunakan algoritma deteksi tepi lain, sehingga dapat menghasilkan tingkat akurasi yang lebih baik. Karena dipengaruhi oleh pergerakan objek dan spesifikasi kamera maka dibutuhkan algoritma yang tepat dan resolusi yang tepat. Citra bergerak jauh berbeda dengan citra diam (citra digital). Video yang digunakan sebagai objek harus diperhatikan variasi, resolusi dan formatnya karena sangat berpengaruh terhadap ketepatan akurasi algoritma dalam mendeteksi tepi objek.

\section{Daftar Pustaka}

[1] W. Supriyatin, "Analisis Perbandingan Pelacakan Objek Menggunakan Optical Flow Dan Background Estimation Pada Kamera Bergerak," ILKOM Jurnal Ilmiah, vol. 11, no. 3, pp. 191-199, 2019.

[2] T. K. Gautama, A. Hendrik and Riskadewi, "Pengenalan Objek Pada Computer Vision Dengan Pencocokan Fitur Menggunakan Algoritma SIFT Studi Kasus : Deteksi Penyakit Kulit Sederhana," JUTISI Jurnal Teknik Informatika dan Sistem Informasi, vol. 2, no. 3, pp. 437-450, 2016.

[3] R. E. Masithoh, B. Rahardjo, L. Sutiarso and A. Hardjoko, "Pengembangan Computer Vision System Sederhana Untuk Menentukan Kualitas Tomat," AGRITECH, vol. 31, no. 2, pp. 116-123, 2011.

[4] N. F. Ardiansyah, A. Rabi, D. Minggu and W. Dirgantara, "Computer Vision Untuk Pengenalan Objek Peluncuran Roket Kendaraan Tempur," JASIEK, vol. 1, no. 1, pp. 28-37, 2019.

[5] Derisma, "Perbandingan Kinerja Metode Deteksi Tepi Pada Pengenalan Objek Menggunakan OpenCV," Jurnal Informatika Mulawarman, vol. 11, no. 2, pp. 17-21, 2016.

[6] I. D. Kurniawati and A. Kusumawardhani, "Implementasi Algoritma Canny Dalam Pengenalan Wajah Menggunakan Antarmuka GUI Matlab," ResearchGate, Surabaya, 2017.

[7] E. Winarno, "Aplikasi Deteksi Tepi Pada Realtime Video Menggunakan Algoritma Canny Detection," Jurnal Teknologi Informasi DINAMIK, vol. 16, no. 1, pp. 44-49, 2011.

[8] M. Nurullah, "Studi Pembanding Deteksi Tepi (Edge Detection) Citra JPEG Dengan Operator Sobel Dan Operator Canny Menggunakan Software Matlab," Universitas Islam Negeri Syarif Hidayatullah, Jakarta, 2014.

[9] M. Indira, E. Yuliana, W. Supriyatin and Bertalya, "Perbandingan Metode Pendeteksian Tepi Studi Kasus : Citra USG Janin," Seminar Ilmiah Nasional Komputer dan Sistem Intelijen (KOMMIT), pp. 366373, 2008.

[10] M. N. Cholis and Y. Fuad, "Aplikasi Deteksi Tepi Sobel Untuk Identifikasi Tepi Citra Medis," MATHunesa, vol. 3, no. 2, pp. 15-19, 2014.

[11] S. Sukatmi, "Perbandingan Deteksi Tepi Citra Digital Dengan Metode Prewitt, Sobel dan Canny," KOPERTIP : Jurnal Ilmiah Manajemen Informatika dan Komputer, vol. 01, no. 01, pp. 1-4, 2017.

[12] A. Apriyana, D. S. Maharani, P. Shinta and R. Angreni, "Perbandingan Metode Sobel, Metode Prewitt dan Metode Robert Untuk Deteksi Tepi Objek Pada Aplikasi Pengenalan Bentuk Berbasis Citra Digital," http://eprints.mdp.ac.id/, Palembang, 2013.

[13] A. Ramdani, "Analisis Deteksi Gerak Multiple Object Dengan Menggunakan Metode Background 
Substracttion Dan Metode Deteksi Tepi Sobel," Universitas Islam Negeri Sultan Syarif Kasim, Riau, 2016.

[14] M. Affandes and A. Ramadani, "Deteksi Gerak Banyak Objek Menggunakan Background Substraction Dan Deteksi Tepi Sobel," Seminar Nasional Teknologi dan Rekayasan (SENTRA), vol. V, pp. V.1-V.6, 2017.

[15] D. Indra, "Pendeteksian Tepi Objek Menggunakan Metode Gradien," Jurnal Ilmiah ILKOM, vol. 8, no. 2, pp. 69-75, 2016.

[16] P. A. Setiyono, "Menganalisa Perbandingan Deteksi Tepi Antara Metode Sobel dan Metode Robet," http://eprints.dinus.ac.id/, Semarang, 2015. 